Ewa M. Guzik-Makaruk

\title{
CZAS POPEKNIENIA PRZESTĘPSTWA I WIEK ODPOWIEDZIALNOŚCI PRAWNOKARNEJ W KODEKSACH KARNYCH REPUBLIKI FEDERALNEJ NIEMIEC, KONFEDERACJI SZWAJCARSKIEJ I AUSTRII
}

\section{Wprowadzenie}

Przedmiotem rozważań uczyniono zagadnienie czasu popełnienia przestepstwa oraz wieku jako granicy odpowiedzialności prawnokarnej. Kwestie te należą do podstawowych problemów prawa karnego, hołdującego wypracowanym w czasach Oświecenia zasadom: „nullum crimen sine lege parlamentaria poenali anteriori” oraz „nullum crimen sine culpa”. Pierwsza z tych zasad oznacza, że nie ma przestępstwa bez ustawy parlamentarnej obowiązującej w chwili popełnienia czynu zabronionego. Aby zatem stwierdzić, że dane zachowanie jest zabronione pod groźbą kary, należy skonfrontować treść ustawy karnej z czasem popełnienia przestępstwa. Czas popełnienia przestępstwa jest poważnym zagadnieniem o znaczeniu praktycznym, o czym świadczyć może uzależnienie wielu następstw od prawidłowego ustalenia tegoż czasu.

Celowość określenia czasu popełnienia przestępstwa przejawia się chociażby w takich obszarach, jak:

- wspomniane wyżej ustalenie, czy czyn w czasie jego popełnienia był zabroniony pod groźbą kary,

- stosowanie zasad intertemporalnych,

- stwierdzenie wieku odpowiedzialności prawnokarnej i rozstrzygnięcie, czy czyn zabroniony został popełniony przez nieletniego czy osobę dorosłą,

- ustalenie winy sprawcy i ewentualne stwierdzenie niepoczytalności w chwili czynu,

- stwierdzenie powrotności do przestępstwa, 
- stwierdzenie przedawnienia,

- zastosowanie aktu amnestyjnego, ${ }^{1}$

- ustalenie, czy przestępstwo zostało popełnione w okresie próby wyznaczonej w związku z popełnieniem innego przestępstwa (warunkowe umorzenie postępowania, warunkowe zawieszenie wykonania kary, warunkowe przedterminowe zwolnienie),

- ustalenie ewentualnych przesłanek do przyjęcia zbiegu przestępstw. ${ }^{2}$

Druga ze wspomnianych na wstępie zasad oznacza, że nie ma odpowiedzialności karnej bez winy, a osiągnięcie przez sprawcę określonego wieku wiąże się w sposób ścisły z możliwością uznania dojrzałości i przypisania winy, co w konsekwencji prowadzić może do ponoszenia przez sprawcę odpowiedzialności karnej.

Podstawą do analizy w niniejszym opracowaniu są regulacje dotyczące tej problematyki w ustawodawstwie karnym wybranych krajów Europy Zachodniej. Państwami tymi są: Republika Federalna Niemiec, Konfederacja Szwajcarska i Austria. Dokonując wyboru wskazanych wyżej porządków prawnych, kierowano się faktem, iż są to regulacje z kręgu niemieckojęzycznej kultury prawnej o ugruntowanej tradycji udokumentowanej chociażby długim czasem obowiązywania.

Kodyfikacja niemiecka, pochodząca z 1871 r., jakkolwiek poddawana wielu zmianom, należy do najstarszych kodyfikacji prawa karnego materialnego w Europie. Konfederacja Szwajcarska także może pochwalić się kodeksem karnym z dość odległą datą uchwalenia, bo przypadającą na pierwszą połowę XX wieku. Szwajcarski kodeks karny pochodzi z 1937 r. i do chwili obecnej podlegał licznym zmianom, wśród których najobszerniejszą stanowi nowelizacja z 2002 r. Weszła ona w życie 1. stycznia 2007 r. i dotyczy także analizowanej w niniejszej publikacji materii. Pozostając w kręgu kodyfikacji niemieckojęzycznych, poddano również analizie ustawodawstwo austriackie z 1974 r., które - jak wskazuje J. Bafia - ,zastapiło kodeks karny z 1852 r., faktycznie zaś ustawodawstwo karne, którego podstawy sięgały 1803 r., a więc ustawodawstwo obowiązujące na terenie Austrii (...) przez lat ponad 170." ${ }^{\prime 3}$

Poniżej zamieszczono rozważania kolejno odnośnie do czasu popełnienia przestępstwa oraz wieku odpowiedzialności karnej w poddanych analizie porządkach prawnych.

\footnotetext{
1 W. Filipkowski, E.M. Guzik-Makaruk, K. Laskowska, G. Szczygieł, E. Zatyka, Przewodnik po prawie karnym, Warszawa 2008, s. 43.

2 G. Bogdan, Z. Ćwiąkalski, P. Kardas, J. Majewski, J. Raglewski, M. Szewczyk, W. Wróbel, A. Zoll, Kodeks karny. Część ogólna. Komentarz. T. I. Komentarz do art. 1-116 kk., wyd. II, Kraków 2004, teza 1.1 do art. 6.

3 J. Bafia, Słowo wstępne, (w:) Austriacki kodeks karny. Ustawa związkowa z dnia 23 stycznia 1974 r. o czynach zabronionych karą sądową, tłum. H. Holder, Warszawa 1980, s. 3, 4.
} 


\section{Analiza rozwiązań prawnych w poszczególnych państwach}

\section{Republika Federalna Niemiec}

Zasadniczą podstawę prawną odpowiedzialności karnej w Republice Federalnej Niemiec stanowią przepisy kodeksu karnego ${ }^{4}$, który - jak wspomniano powyżej należy do najstarszych kodyfikacji prawa karnego materialnego w Europie. Od czasu uchwalenia pierwotnej wersji tekst ulegał wielokrotnym zmianom, a sama kodyfikacja pojawiła się już w 1871 r., na początku panowania cesarstwa Hohenzollernów i kanclerstwa Otto von Bismarcka, tuż po powstaniu II Rzeszy Niemieckiej. Była to pierwsza jednolita regulacja, która obowiązywała na terytorium całej Rzeszy Niemieckiej, zawierając klarownie i prosto skonstruowane przepisy, które nawet do dnia dzisiejszego przetrwały w niemal niezmienionej formie. Przykładem może być $§ 242$ StGB penalizujący kradzież. ${ }^{5}$

Kodeks przetrwał zawirowania dziejowe - Republikę Weimarską, III Rzeszę i po zjednoczeniu Niemiec w 1990 r. ${ }^{6}$ obowiązuje na terytorium nowo ukształtowanej Republiki Federalnej Niemiec ${ }^{7}$.

Podstawowa regulacja prawnokarna odnośnie do czasu popełnienia przestępstwa znajduje swoje odzwierciedlenie w $\S 8$ StGB, zatytułowanym „Zeit der Tat”, czyli „Czas czynu”. Przepis ten stanowi ${ }^{8}$, że czyn jest popełniony w czasie, w którym sprawca albo uczestnik działał, a w przypadku zaniechania miał podjąć działanie. Czas wystapienia skutku nie jest miarodajny.

Z treści przywołanego przepisu wynika, że nastąpienie skutku jest irrelewantne z punktu widzenia ustawodawcy niemieckiego, który oparł się w $§ 8$ StGB na czasie działania lub zaniechania sprawcy bądź współuczestnika w czynie przestępnym. To właśnie czas działania lub zaniechania jest miarodajny dla przyjęcia określonego czasu popełnienia przestępstwa. ${ }^{9} \mathrm{Z}$ przepisów $\S 25-\S 31$ StGB wynika, że uczestnikiem czynu zabronionego jest współsprawca, podżegacz i pomocnik.

Z kryminalnopolitycznego punktu widzenia takie ukształtowanie $\S 8$ StGB, abstrahującego od teorii wszędobylstwa ${ }^{10}$ (akcentowanej w $§ 9$ StGB przy regulacji odnośnie do miejsca popełnienia przestępstwa) służy realizacji zakazu nieretroakcji

4 Das Strafgesetzbuch (StGB) vom 15. Mai 1871, RGBI 1871, 127 mit weiteren Änderungen.

5 W. Joecks, (w:) W. Joecks, K. Miebach (red.), Münchener Kommentar zum StGB, Band 1, 1. Auflage, München 2003, Einleitung, Rn 78.

$6 \quad$ Vertrag zwischen der Bundesrepublik Deutschland und der Deutschen Demokratischen Republik über die Herstellung der Einheit Deutschlands (Einigungsvertrag) vom 31. August 1990, BGBI II 1990, 889.

$7 \quad$ Zjednoczenie Niemiec nastapiło w dniu 3. października 1990 r. na mocy porozumienia zawartego podczas moskiewskiej konferencji „dwa plus cztery” (RFN, NRD plus Francja, USA, Wielka Brytania i ZSRR).

8 "§ 8 Zeit der Tat. Eine Tat ist zu der Zeit begangen, zu welcher der Täter oder der Teilnehmer gehandelt hat oder im Falle des Unterlassens hätte handeln müssen. Wann der Erfolg eintritt, ist nicht maßgebend."

9 U. Kindhäuser, Strafrecht. Allgemeiner Teil, Baden-Baden 2005, s. 44.

10 Ubiquitätstheorie. 
prawa karnego. Nie może być bowiem tak, że będzie karany sprawca czynu, który nie jest penalizowany w chwili jego podjęcia, w sytuacji, gdy sam skutek czynu następuje pod rządami nowej zmienionej ustawy karnej, kryminalizującej zachowanie uprzednio nieobwarowane kara. ${ }^{11}$

Nieco inna reguła występuje $\mathrm{w} \S 78 \mathrm{a} \mathrm{StGB}^{12}$, który dotyczy rozpoczęcia biegu terminu przedawnienia. Przepis ten stanowi, że termin przedawnienia biegnie od momentu zakończenia czynu, jednak gdy skutek należący do znamion czynu zabronionego następuje później, termin przedawnienia zaczyna biec dopiero od tej chwili. $Z$ treści tego przepisu wynika zatem, że miarodajnym dla przyjęcia terminu przedawnienia może być bądź czas popełnienia przestępstwa bądź moment nadejścia skutku, jeśli jest późniejszy od czasu działania lub zaniechania działania.

Pomimo że w literaturze krytykuje się mało klarowny sposób technicznej redakcji tegoż przepisu ${ }^{13}$, podkreśla się jednak potrzebę zaakcentowania różnicy między czasem zakończenia czynu a czasem wystąienia skutku jako początkowego terminu biegu przedawnienia, zwłaszcza w przypadku, gdy występuje duża czasowa dyferencja pomiędzy czasem działania sprawcy a czasem nastąpienia skutku. ${ }^{14}$

Wypada zauważyć, że polska prawnokarna regulacja tego zagadnienia jest bardzo podobna, albowiem w art. $101 \S 1$ kodeksu karnego ${ }^{15}$ ustawodawca podaje terminy przedawnienia, określając początkowy termin biegu ich przedawnienia jako czas popełnienia przestępstwa, zaś w art. $101 \S 3 \mathrm{kk}$. postanawia, że jeśli dokonanie przestępstwa zależy od nastąpienia określonego w ustawie skutku, bieg przedawnienia rozpoczyna się od czasu, gdy skutek nastąpił. Także podobnie ustawodawca polski podszedł do regulacji odnośnie do czasu popełnienia przestępstwa, stanowiąc w art. $6 \S 1$ kk., że czyn zabroniony uważa się za popełniony w czasie, w którym sprawca działał lub zaniechał działania, do którego był obowiązany.

Analizując problematykę wieku odpowiedzialności prawnokarnej, należy odnieść się nie tylko do przepisów niemieckiego kodeksu karnego, ale także do ustawy o sądach dla nieletnich ${ }^{16}$.

Stosownie do ogólnej zasady niemieckiego materialnego prawa karnego, wyrażonej w ujęciu negatywnym w $§ 19$ StGB, podmiotem czynu przestępnego może flage, München 2003, § 8, Rn 1; A. Eser, (w:) A. Schönke, H. Schröder, Strafgesetzbuch. Kommentar, 27. Auflage, München 2006, § 8, Rn 1. erst später ein, so beginnt die Verjährung mit diesem Zeitpunkt."

13 Th. Fischer, Strafgesetzbuch und Nebengesetze, 56. Auflage, München 2009, t. 2 do § 78a, s. 762.

14 K. Lackner, K. Kühl, (w:) K. Kühl (red.), Strafgesetzbuch. Kommentar, 26. Auflage, München 2007, § 78a, Rn 1.

15 Ustawa z dnia 6. czerwca 1997 r. Kodeks karny, Dz.U. Nr 88 poz. 553 ze zm.

$16 \S 1$ Jugendgerichtsgesetz (JGG) vom 4. August 1953, BGBI I 1953, 751. 
być osoba, która ukończyła lat 14 w chwili popełnienia czynu ${ }^{17}$. Warto zwrócić uwagę, że niemiecki kodeks karny w $§ 176$ Abs. 1 postanawia, że osoba w wieku poniżej 14 lat jest dzieckiem. ${ }^{18}$ Takie określenie wynika $\mathrm{z}$ udowodnionych w nauce pedagogiki i psychologii deficytów dojrzałości u osób w wieku poniżej lat $14{ }^{19}$

Jak wspomniano, kodeks karny reguluje zagadnienie zdolności do zawinienia w sposób negatywny. Nie definiuje zdolności do zawinienia (Schuldfähigkeit), lecz wymienia przesłanki, których spełnienie wyłącza możliwość przypisania winy ( $\S \S$ 19, $20 \mathrm{StGB}) .{ }^{20} \mathrm{~W}$ przepisie $\S 19 \mathrm{StGB}$ postanowiono, że niezdolna do ponoszenia winy jest osoba, która w chwili popełnienia czynu nie miała ukończonych lat 14. Kolejny przepis odnoszący się do wyłączenia elementu winy dotyczy działania w stanie niepoczytalności w chwili czynu (§ 20 StGB).

Porównanie przepisów kodeksu karnego oraz ustawy o sądach dla nieletnich ${ }^{21}$ pozwala stwierdzić, że przepisy kodeksu karnego w pełnej rozciągłości mają zastosowanie dopiero do sprawcy, który w chwili czynu miał ukończone lat 21.

Osoby pomiędzy 14 a 18 rokiem życia traktowane są jako nieletnie, między 18 a 21 rokiem życia jako młodociane. Obie te kategorie podmiotów podlegają przepisom wspomnianej już ustawy o sądach dla nieletnich, będących porównywalnym odpowiednikiem polskiej ustawy o postępowaniu w sprawach nieletnich. Ustawa przewiduje dość bogaty katalog środków wychowawczych, karcenia i poprawczych, włącznie z aresztem dla nieletniego oraz karą pozbawienia wolności wykonywaną w zakładach karnych dla nieletnich ${ }^{22}$. Podstawąjej stosowania jest popełnienie czynu, który wyczerpuje znamiona określone w ustawie karnej jako przestępstwo w formie zbrodni lub występku (§ 4 ustawy JGG).

Rzeczowo właściwym do orzekania w sprawach nieletnich jest zawsze sąd dla nieletnich ( $\$ 33$ ustawy JGG), zaś do prowadzenia postępowania sądowego względem młodocianych właściwy może być sąd dla sprawców dorosłych, jeśli stopień rozwoju młodocianego na to pozwala.

W praktyce istnieje tendencja do stosowania względem sprawców młodocianych przepisów ustawy o sądach dla nieletnich. Tendencja ta wzrasta odwrotnie proporcjonalnie do wieku sprawcy w ten sposób, iż im bardziej zbliżony wiek młodocianego do ustawowej dolnej granicy między nieletnim a młodocianym (18 lat), tym

17 „§ 19 Schuldunfähigkeit des Kindes. Schuldunfähig ist, wer bei Begehung der Tat noch nicht vierzehn Jahre alt ist."

18 „\$176 Sexueller Mißbrauch von Kindern. (1) Wer sexuelle Handlungen an einer Person unter vierzehn Jahren (Kind) vornimmt oder an sich von dem Kind vornehmen läßt, wird mit Freiheitsstrafe von sechs Monaten bis zu zehn Jahren bestraft. (...)"

19 B. von Heintschel-Heinegg, Beck'scher Online-Kommentar, Stand: 1.10.2009, § 19, Rn 20.

20 U. Kindhäuser, op. cit., s. 173.

$21 \S 1$ Jugendgerichtsgesetz (JGG) vom 4. August 1953, BGBI I 1953, 751.

$22 \S 17$ ustawy zakreśla zasadniczo ramy czasowe tej kary względem nieletniego od 6 miesięcy do 5 lat, § 105 od 6 miesięcy do 10 lat wobec młodocianego. 
większa potrzeba kompetencji sądu dla nieletnich przed sądem dla sprawców doro$\mathrm{słych}^{23}$.

W postępowaniu ze sprawcami młodocianymi prym wiedzie zasada pierwszeństwa sądów dla nieletnich przed sądami dla dorosłych. Do własnego i autonomicznego rozstrzygnięcia przez sądy dla nieletnich pozostaje kwestia ich właściwości. Sądy te podejmują decyzję, czy stopień rozwoju sprawcy, jego właściwości i warunki osobiste pozwalają na prowadzenie względem niego postępowania na zasadach ogólnych, przez sądy dla dorosłych ${ }^{24}$.

Po dokonaniu analizy przepisów kodeksu karnego oraz ustawy o sądach dla nieletnich można postawić tezę, że sprawcą zawsze odpowiadającym na podstawie kodeksu karnego jest ten, który ukończył 21 rok życia w chwili popełnienia czynu zabronionego, a wyjątkowo - przy zastosowaniu § 105 ustawy o sądach dla nieletnich - młodociany po ukończeniu 18 roku życia, pod warunkiem, że sąd dla nieletnich po dokonaniu oceny stopnia rozwoju sprawcy przekaże sprawę do rozpoznania sądowi dla dorosłych. ${ }^{25}$ Warto w tym miejscu zaznaczyć, iż z $§ 10$ StGB zatytułowanego ,przepisy szczególne względem nieletnich i młodocianych”26 jasno wynika, że przepisy kodeksu karnego stosuje się tylko subsydiarnie do przepisów ustawy o sądach dla nieletnich. Zatem w odniesieniu do czynów popełnionych przez sprawców nieletnich lub młodocianych stosuje się przepisy kodeksu karnego tylko o tyle, o ile inaczej nie postanowiono w ustawie o sądach dla nieletnich. ${ }^{27}$

Wprawdzie sprawcy młodociani powinni być generalnie postrzegani jako zdolni do ponoszenia odpowiedzialności prawnokarnej na zasadach ogólnych kodeksu karnego, jednak przy zastosowaniu $\S 105$ JGG trzeba w każdym wypadku zbadać stopień rozwoju i dojrzałości sprawcy, analizując, czy bardziej celowe byłoby procedowanie w oparciu o ustawę o sądach dla nieletnich, czy na podstawie kodeksu karnego. Należy wszak pamiętać, że nawet w sytuacji, gdy postępowanie prowadzone jest przy zastosowaniu kodeksu karnego, wyłączone jest chociażby stosowanie niektórych kar, jak dożywotnie pozbawienie wolności. ${ }^{28}$

\footnotetext{
23 U. Eisenberg, Jugendgerichtsgesetz mit Erläuterungen, München 1993, s. 836.

24 R. Brunner, D. Dölling, Jugendgerichtsgesetz. Kommentar, Berlin 1996, s. 56.

25 U. Kindhäuser, op. cit., s. 173.

26 W tym miejscu należy poczynić pewną uwagę, dotyczącą techniki prawodawczej w RFN. Otóż, odmiennie niż w Polsce, ustawodawca niemiecki zawiera w tekstach prawa obowiązującego nazwy wszystkich przepisów części ogólnej StGB oraz nazwy wszystkich typów czynów zabronionych. Tutaj: „§ 10. Sondervorschriften für Jugendliche und Heranwachsende". senden gilt dieses Gesetz nur, soweit im Jugendgerichtsgesetz nicht anderes bestimmt ist".

28 A. Eser (w:) A. Schönke, H. Schröder, Strafgesetzbuch. Kommentar, 27. Auflage, München 2006, § 10, Rn 3.
} 


\section{Konfederacja Szwajcarska}

Odpowiedzialność za czyny zabronione pod groźbą kary w Konfederacji Szwajcarskiej oparta jest głównie na przepisach kodeksu karnego ${ }^{29}$. Akt ten został uchwalony w 1937 r. i wszedł w życie w dniu 1. stycznia 1942 r. Do dnia dzisiejszego ulegał wielokrotnym zmianom, jednak najbardziej obszerne z nich obowiązują od dnia 1. stycznia $2007 \mathrm{r}$.

Wielka reforma prawa karnego została zapoczątkowana w 2002 r., kiedy to przygotowano wiele ustaw zmieniających dotychczasowe przepisy, wśród których największa nowelizacja kodeksu karnego została przygotowana w ustawie zmieniającej kodeks karny z $2002 \mathrm{r}^{30} \mathrm{i}$ ustawie o postępowaniu w sprawach nieletnich z 2003 r. ${ }^{31} \mathrm{~W}$ efekcie tych działań ustawodawczych początek 2007 r. przyniósł wejście $\mathrm{w}$ życie ponad 20 ustaw z zakresu prawa karnego materialnego i formalnego, w tym takich przepisów, jak np. ustawa karna nieletnich ${ }^{32}$, wojskowy kodeks karny ${ }^{33}$, ustawa o federalnym wymiarze sprawiedliwości ${ }^{34}$ (odpowiednik polskiej ustawy o ustrojach sądów powszechnych), ustawa o pomocy międzynarodowej w sprawach karnych ${ }^{35}$ czy administracyjne prawo karne (odpowiednik polskiego kodeksu wykroczeń) ${ }^{36}$.

Obowiązujący kodeks karny nie zawiera regulacji odnoszących się wprost do czasu popełnienia przestępstwa. W art. 2 szwajcarskiego $\mathrm{StGB}^{37}$, zatytułowanym „Zeitlicher Geltungsbereich”, czyli „Czasowy zakres obowiązywania” postanowiono, że odpowiedzialności prawnokarnej na podstawie kodeksu podlega ten, kto popełnia zbrodnię lub występek po wejściu w życie ustawy. Jeśli sprawca popełnia zbrodnię lub występek przed wejściem w życie niniejszej ustawy, orzekanie przebiega w oparciu o tę ustawę, która jest dla sprawcy łagodniejsza. Jak podkreśla G. Heine, przy wyborze ustawy łagodniejszej sąd bierze przede wszystkim pod uwagę sy-

29 Strafgesetzbuch vom 21. Dezember 1937, SR (Systematische Sammlung des Bundesrechts) 311.

30 Schweizerisches Strafgesetzbuch, Änderung vom 13. Dezember 2002, BBI 2002, 8240. Ustawa weszła w życie w dniu 1. stycznia 2007 r.

31 Bundesgesetz vom 20. Juni 2003 über das Jugendstrafrecht (Jugendstrafgesetz, JGG), SR (Systematische Sammlung des Bundesrechts) 311.1. Ustawa weszła w życie w dniu 1. stycznia $2007 \mathrm{r}$.

32 Bundesgesetz vom 20. Juni 2003 über das Jugendstrafrecht (Jugendstrafgesetz, JStG), SR (Systematische Sammlung des Bundesrechts) 311.1. Ustawa weszła w życie w dniu 1. stycznia $2007 \mathrm{r}$.

33 Militärstrafgesetz vom 13. Juni 1927. Änderung vom 21. März 2003, SR (Systematische Sammlung des Bundesrechts) 321.0. Ustawa weszła w życie w dniu 1. stycznia $2007 \mathrm{r}$.

34 Bundesgesetz vom 15. Juni 1934 über die Bundesstrafrechtspflege. Änderung vom 17. Juni 2003, SR (Systematische Sammlung des Bundesrechts) 312.0. Ustawa weszła w życie w dniu 1. stycznia $2007 \mathrm{r}$.

35 Bundesgesetz vom 20. März 1981 über internationale Rechtshilfe in Strafsachen. Änderung vom 13. Dezember 2003, SR (Systematische Sammlung des Bundesrechts) 351.1. Ustawa weszła w życie w dniu 1. stycznia 2007 r.

36 Bundesgesetz vom 22. März 1974 über das Verwaltungsstrafrecht. Änderung vom 20. Juni 2003, SR (Systematische Sammlung des Bundesrechts) 313.0. Ustawa weszła w życie w dniu 1. stycznia 2007 r.

37 „Art. 2 Zeitlicher Geltungsbereich. 1 Nach diesem Gesetze wird beurteilt, wer nach dessen Inkrafttreten ein Verbrechen oder Vergehen begeht. 2 Hat der Täter ein Verbrechen oder Vergehen vor Inkrafttreten dieses Gesetzes begangen, erfolgt die Beurteilung aber erst nachher, so ist dieses Gesetz anzuwenden, wenn es für ihn das mildere ist." 
stem sankcji i rozmiar ograniczeń praw i wolności przez nie przewidzianych, przy czym niedopuszczalne jest częściowe stosowanie ustawy nowej i poprzednio obowiązującej. Wykluczona jest taka kompilacja, a sąd dokonuje wyboru jednego aktu prawnego. Wspomniany Autor podaje jednocześnie, że w bardzo wielu przypadkach korzystniejsza będzie ustawa - kodeks karny w swym kształcie po nowelizacji, która weszła w życie w 2007 r. ${ }^{38}$ S. Trechsel i P. Noll zauważają, że przy stosowaniu art. 2 Abs. 1 StGB miarodajny jest czas działania sprawcy, gdyż tylko w ten sposób można zachować sens zasady gwarancyjnej prawa karnego. W przypadku, gdy do znamion czynu należy więcej zachowań, czasem jego popełnienia będzie ostatnie zachowanie z podjętych przez sprawcę. ${ }^{39} \mathrm{~W}$ przypadku czynów formalnych, a zatem bezskutkowych, dodatkowo których istota polega na zaniechaniu, czasem ich popełnienia według powszechnie przyjętej w doktrynie teorii jest czas, w którym sprawca mógł podjąć działanie. Materialne przestępstwa z zaniechania, które są znamienne skutkiem, wymagają dla swego istnienia podmiotu będącego gwarantem nienastapienia skutku przestępnego Obowiązek podjęcia określonego działania może wynikać z ustawy, umowy czy konkretnych okoliczności, w jakich znajduje się sprawca. ${ }^{40}$

Analizując problematykę wieku odpowiedzialności prawnokarnej, podobnie jak w przypadku porządku prawnego Republiki Federalnej Niemiec, należy posłużyć się nie tylko kodeksem karnym, ale także ustawą karną dla nieletnich.

Do dnia 1. stycznia 2007 r., jako daty wejścia w życie nowelizacji kodeksu karnego, kodeks w aspekcie odpowiedzialności karnej rozróżniał cztery kategorie podmiotów, biorąc pod uwagę osiagnięty wiek chwili czynu:

1. dzieci do lat 7 nie ponosiły żadnej odpowiedzialności karnej (art. 82 ust. 1 StGB);

2. osoby pomiędzy 7 a 15 rokiem życia ponosiły ograniczoną odpowiedzialność karną (art. 82 ust. 2 StGB);

3. sprawcy pomiędzy 15 a 18 rokiem życia traktowani byli jako nieletni (art. 89 StGB);

4. młodociani jako osoby, które ukończyły 18 rok życia przed osiagnięciem 25 lat (art. $100 \mathrm{StGB}$ ), traktowani byli w zasadzie jako sprawcy dorośli, z wy-

G. Heine, Fragenkatalog AT-StGB - neu für in dubio 01/07, http://www.krim.unibe.ch/unibe/rechtswissenschaft/ isk/content/e723/e1299/e1302/files1304/Fragenkatalog_indubio_1.2.07_ger.pdf, s. 8.

39 S. Trechsel, P. Noll, Schweizerisches Strafrecht. Allgemeiner Teil I, Allgemeine Voraussetzungen der Strafbarkeit, 5. Auflage, http://64.233.183.104/search?q=cache:d5W27MU-dQkJ:www.concordia-bern.ch/ Dokumente\%2520Jus-Portal/Strafrecht/StGB\%2520AT\%2520Zusammenfassung\%2520Trechsel\%2520Noll. doc+Trechsel/Noll+\%22Allgemeine+Voraussetzungen+der+Strafbarkeit\%22\&hl=pl\&ct=clnk\&cd=1\&gl=pl, s. 9. K.L. Kunz, Interaktives Lernsystem mit CD_Rom, Schweizerisches Strafrecht. Allgemeiner Teil, Basel 2000, s. $149,152-154$. 
jątkami wynikającymi z art. 100 bis i art. 100 ter StGB, pozwalającymi na ich łagodniejsze karanie.

Na podstawie obowiązujących od 1. stycznia 2007 r. przepisów szwajcarskiego kodeksu karnego odpowiada obecnie osoba, która w chwili czynu ukończyła 18 rok życia. ${ }^{41}$ Sprawcy czynów zabronionych popełnionych przed osiagnięciem tego wieku podlegają reżimowi ustawy karnej dla nieletnich.

Ustawa karna dla nieletnich stanowi w art. 1, że jej przepisy mają zastosowanie względem osób, które przed ukończeniem 18 roku życia popełniły czyn zabroniony pod groźbą kary przez kodeks karny, bądź przez inną federalną ustawę karną. W art. 3 ustawy doprecyzowano, że obowiązuje ona względem osób, które popełniły czyn karalny po ukończeniu 10 roku życia, a przed ukończeniem 18 lat. Wprowadzono pewne dodatkowe rozróżnienia, odnoszące się jednak tylko do możliwości orzeczenia określonych środków, np. karę pieniężną w wysokości do 2000 SFr można orzec wobec nieletniego, który w chwili popełnienia zbrodni lub występku ukończył lat 15 (art. 24 JStG). Względem takiego sprawcy można także orzec środek polegający na pozbawieniu wolności od 1 dnia do roku (art. 25 ust. 1 JStG). Względem sprawcy, który dopuścił się zbrodni po ukończeniu 16 roku życia, można orzec środek polegający na pozbawieniu wolności od 1 dnia do 4 lat (art. 25 ust. 2 JStG). ${ }^{42}$ Jak podkreśla G. Heine, u podstaw ustawy karnej dla nieletnich nie leżą cele sprawiedliwego karania jako odpłaty za czyn zabroniony ani też cele prewencyjne, gdyż dla wielu nieletnich popełnienie czynu zabronionego stanowi tylko jednorazowy epizod w ich młodzieńczym życiu. Głównym założeniem ustawy jest możliwość wspierającej i wychowawczej interwencji państwowej, jednak z drugiej strony w praktyce występują przypadki, gdy nieletni bez skrupułów popełniają najcięższe zbrodnie. Dla takich właśnie przypadków, gdy nieletni po ukończeniu 16 roku życia dopuszcza się zbrodni, przewidziano środek polegający na pozbawieniu wolności. ${ }^{43}$

Warto wspomnieć, że ustawa karna dla nieletnich posługuje się jedynie pojęciem nieletniego, nie wprowadzając kategorii sprawcy młodocianego. Także kodeks karny Konfederacji Szwajcarskiej nie wyodrębnia sprawców młodocianych jako szczególnych podmiotów oddziaływania prawnokarnego. Nowa regulacja wprowadziła zatem zupełnie inny reżim w zakresie kategoryzacji sprawców pod względem osiagniętego przez nich wieku.

41 Art. 9 ust. 2 StGB.

42 Podstawowe założenia nowej ustawy zob.: R. Walther, Das neue Jugendstrafrecht - ein Überblick, artykuł zamieszczony na oficjalnej stronie internetowej Prokuratury w St. Gallen, www.staatsanwaltschaft.sg.ch. 


\section{Austria}

Główną podstawę prawną odpowiedzialności karnej w Republice Austrii stanowią przepisy kodeksu karnego ${ }^{44}$. Regulacja odnośnie do czasu popełnienia przestępstwa znajduje się w $\S 67 \mathrm{StGB}^{45}$, zatytułowanym „Zeit und Ort der Tat”, czyli „Czas i miejsce czynu”. W $§ 67$ Abs. 1 StGB ustawodawca austriacki postanowił, że czyn sprawcy zagrożony karą popełniony jest w czasie, w którym sprawca działał, a w przypadku zaniechania miał podjąć działanie. Czas wystapienia skutku nie jest miarodajny. Jest to zatem regulacja analogiczna do obu wyżej omówionych.

Podobnie jak w przypadku Republiki Federalnej Niemiec czy Konfederacji Szwajcarskiej, analizując problematykę wieku, celowym jest posłużenie się nie tylko kodeksem karnym, ale także przepisami federalnej ustawy o wymiarze sprawiedliwości w sprawach czynów popełnionych przez osoby nieletnie.

Obowiązujący austriacki kodeks karny wszedł w życie w dniu 1. stycznia 1975 r. W żadnym z przepisów nie kategoryzuje sprawców pod względem wieku. Wprawdzie w $\S 74$ ust. 1 i 3 StGB zawierają wyjaśnienie wyrażeń ustawowych ,nieletniego” (unmündig) oraz „małoletniego” (minderjährig), jednak ta ustawodawcza wykładnia posiada odniesienie do ofiar przestępstw, a nie ich sprawców. Nabiera to szczególnego znaczenia zwłaszcza w przypadku penalizacji czynów zabronionych skierowanych przeciwko integralności seksualnej i samostanowieniu w sferze wolności seksualnej (rozdział X StGB), gdzie osoby nieletnie i małoletnie pozostają pod specjalną ochroną.

Stosownie do $\S 74$ ust. 1 i 3 StGB osobą nieletnią jest ten, kto nie ukończył 14 roku życia, zaś osobą małoletnią ten, kto nie ukończył 18 lat. Kodeks karny w części ogólnej zwraca uwagę na wiek sprawcy, czyniąc to jedynie w § 36 StGB. Przepis ten zawiera szczegółowe postanowienia w zakresie wymiaru kary pozbawienia wolności względem osób, które w chwili czynu nie miały ukończonych 21 lat. Wobec takich osób nie można orzekać kary dożywotniego pozbawienia wolności, a przewidziany ustawowy wymiar terminowej kary pozbawienia wolności musi obligatoryjnie ulec sądowej modyfikacji. W tym aspekcie można by wysunąć tezę, iż sprawcy czynów zabronionych dokonanych przed ukończeniem 21 roku życia zostali w pewien sposób wyróżnieni przez ustawodawcę, ale nie zostali zakwalifikowani jako sprawcy młodociani. Ustawa posługuje się jedynie pojęciem „osoby”, która nie ukończyła 21 roku życia, nie nazywając jej w żaden szczególny sposób. H. Fuchs określa osoby w wieku pomiędzy 18 a 21 rokiem życia jako „Junge Erwachsene”, a zatem „młodych dorosłych”. ${ }^{46}$

\footnotetext{
44 Bundesgesetz vom 23. Jänner 1974 über die mit gerichtlicher Strafe bedrohten Handlungen (Strafgesetzbuch, StGB), BGBI Nr 60/1974 ze zm.

45 "Zeit und Ort der Tat. § 67. (1) Eine mit Strafe bedrohte Handlung hat der Täter zu der Zeit begangen, da er gehandelt hat oder hätte handeln sollen; wann der Erfolg eintritt, ist nicht maßgebend. (...)"

46 H. Fuchs, Österreichisches Strafrecht. Allgemeiner Teil I, 6. Auflage, Wien-New York 2004, s. 13.
} 
W celu wyjaśnienia kto odpowiada wyłącznie na zasadach określonych w kodeksie karnym, a kim jest sprawca nieletni, konieczna jest analiza postanowień federalnej ustawy o wymiarze sprawiedliwości w sprawach czynów popełnionych przez osoby nieletnie. ${ }^{47}$ Ustawa owa wprowadza w $\S 1$ określenie dwóch kategorii osób nieletnich, w dalszych postanowieniach wiążąc z pierwszą kategorią niekaralność czynów zabronionych popełnianych przez sprawców nią objętych (§ 4 ust. 1). Ta pierwsza kategoria to osoby, które nie ukończyły lat 14 (§ 1 ust. 1 ustawy).

Druga kategoria nieletnich to osoby, które ukończyły 14 rok życia, ale nie ukończyły 19 lat ( $§ 1$ ust. 2 ustawy). Na mocy $\S 5$ ustawy przy wymierzaniu kary nieletnim (którzy są w wieku między 14 a 19 rokiem życia), stosuje się przepisy ogólne ustaw karnych z wyjątkami określonymi w powołanym $\S 5$ ustawy. Przepis ten zawiera postanowienie, zgodnie z którym zastosowanie kary względem nieletniego ma mieć charakter indywidualnoprewencyjny i przede wszystkim cel odwiedzenia nieletniego od popełnienia czynu zabronionego w przyszłości. W dalszej kolejności ustawodawca zawarł dyrektywy w zakresie modyfikacji ustawowego wymiaru kary względem sprawców nieletnich, stanowiąc przykładowo, że w miejsce przewidzianej kary dożywotniej kary pozbawienia wolności wchodzi kara pozbawienia wolności od roku do 15 lat, jeśli sprawca popełnił czyn zabroniony po ukończeniu 16 lat, bądź od roku do 10 lat w przypadku sprawców popełniających czyny zabronione pomiędzy 14 a 16 rokiem życia.

Chcąc podsumować regulacje austriackie, należałoby zwrócić uwagę na następujące kwestie:

1. osoby, które w chwili popełnienia czynu zabronionego miały ukończone 21 lat, ponoszą odpowiedzialność na zasadach ogólnych kk., a zatem chociaż ustawodawca nie używa takiej nomenklatury, należy je traktować jak sprawców dorosłych;

2. osoby, które w chwili popełnienia czynu nie ukończyły 21 roku życia, ponoszą odpowiedzialność na zasadach ogólnych kk. z łagodzącymi ograniczeniami w zakresie wymiaru kary pozbawienia wolności, przewidzianymi $\mathrm{w} \S 36 \mathrm{kk}$.,

3. osoby pomiędzy 14 a 19 rokiem życia ponoszą odpowiedzialność na zasadach ogólnych kk. z ograniczeniami w zakresie wymiaru kary, przewidzianymi w ustawie o wymiarze sprawiedliwości w sprawach czynów popełnionych przez osoby nieletnie, co skutkuje ich zdecydowanie łagodniejszą odpowiedzialnością, 
4. osoby poniżej 14 roku życia nie ponoszą odpowiedzialności za czyny zabronione pod groźbą kary.

\section{Podsumowanie}

Regulacje dotyczące czasu popełnienia przestępstwa w kodeksach karnych wybranych państw wykazują pewne różnice. Zarówno kodeks karny Republiki Federalnej Niemiec, jak i Austrii zawierają przepisy wprost odnoszące się do tej problematyki. Kodeks karny Konfederacji Szwajcarskiej do czasu popełnienia przestępstwa odnosi się pośrednio przy okazji normowania czasowego zakresu obowiązywania ustawy karnej. Pomimo mniej lub bardziej rozbudowanych konstrukcji, można stwierdzić, że przyjęte rozwiązania są analogiczne. W zamieszczonej poniżej tabeli dokonano zestawienia i przeglądu przepisów dotyczących czasu popełnienia przestępstwach w trzech wybranych kodeksach karnych.

Tabela 1. Czas popełnienia przestępstwa

\begin{tabular}{|c|c|}
\hline Kraj & Regulacja \\
\hline $\mathrm{N}$ & $\begin{array}{l}\text { § } 8 \text { StGB, zatytułowany „Zeit der Taf”, czyli "Czas czynu”. Czyn jest popełniony w czasie, } \\
\text { w którym sprawca albo uczestnik działał, a w przypadku zaniechania miał podjąć działanie. } \\
\text { Czas wystąpienia skutku nie jest miarodajny. }\end{array}$ \\
\hline$S$ & $\begin{array}{l}\text { Obowiązujący kodeks karny nie zawiera regulacji odnoszących się wprost do czasu popełnie- } \\
\text { nia przestępstwa. Art. } 2 \text { StGB, zatytułowany „Zeitlicher Geltungsbereich”, czyli „Czasowy zakres } \\
\text { obowiązywania” postanawia, że odpowiedzialności prawnokarnej na podstawie kodeksu podle- } \\
\text { ga ten, kto popełnia zbrodnię lub występek po wejściu w życie ustawy. Jeśli sprawca popełnia } \\
\text { zbrodnię lub występek przed wejściem w życie niniejszej ustawy, orzekanie przebiega w opar- } \\
\text { ciu o tę ustawę, która jest dla sprawcy łagodniejsza. }\end{array}$ \\
\hline$A$ & $\begin{array}{l}\text { W } \S 67 \text { Abs. } 1 \text { StGB, zatytułowanym „Zeit und Ort der Tat”, czyli „Czas i miejsce czynu” posta- } \\
\text { nowiono, że czyn sprawcy zagrożony karą popełniony jest w czasie, w którym sprawca działał, } \\
\text { a w przypadku zaniechania miał podjąć działanie. Czas wystąienia skutku nie jest miarodajny. }\end{array}$ \\
\hline
\end{tabular}

Regulacje w zakresie wieku odpowiedzialności prawnokarnej w wybranych państwach zawarte są w kodeksach karnych i ustawach dotyczących nieletnich. Kwestie odpowiedzialności nieletnich uregulowano w Republice Federalnej Niemiec ustawą o sądach dla nieletnich (Jugendgerichtsgesetz), w Konfederacji Szwajcarskiej ustawą karną dla nieletnich (Jugendstrafgesetz), zaś w Austrii ustawą o wymiarze sprawiedliwości w sprawach czynów popełnionych przez osoby nieletnie (Bundesgesetz über die mit gerichtlicher Strafe bedrohten Handlungen). 
W systemie szwajcarskim i austriackim kategoryzuje się dwie grupy podmiotów ze względu na osiągnięty wiek w chwili popełnienia czynu zabronionego. Są to osoby, które odpowiadają na zasadach określonych w kodeksie karnym oraz sprawcy nieletni, którzy odpowiadają bądź mogą odpowiadać po spełnieniu określonych warunków przewidzianych w ustawie karnej.

Ustawodawstwo niemieckie wyróżnia jeszcze sprawców młodocianych, czego nie czynią pozostałe dwie regulacje. Zgodnie z $§ 1$ ust. 2 niemieckiej ustawy o sądach dla nieletnich, młodocianym jest osoba, która w czasie popełnienia czynu zabronionego miała ukończone lat 18 , ale nie ukończyła lat 21 . Ustawodawca niemiecki, określając status młodocianego, przyjął jedynie kryterium wieku sprawcy w czasie popełnienia przestępstwa, abstrahując od innych okoliczności, jak np. czas orzekania w I instancji, na co wskazuje chociażby art. $115 \S 10$ polskiego kodeksu karnego.

Granica wieku ponoszenia odpowiedzialności karnej została ustalona na poziomie 18 lat w kodeksie karnym szwajcarskim oraz 21 lat w kodeksach karnych Republiki Federalnej Niemiec i Austrii. Zbiorcze zestawienie odnośnych przepisów zawiera poniższa tabela 2 .

Tabela 2. Wiek odpowiedzialności karnej

\begin{tabular}{|c|l||}
\hline Kraj & \multicolumn{1}{|c|}{ Wiek } \\
\hline $\mathrm{N}$ & $\begin{array}{l}\text { Z brzmienia § 1 ust. 2 ustawy o sądach dla nieletnich (JGG) można wnioskować, że sprawcą } \\
\text { wobec którego można orzec katalog kar bez żadnych ograniczeń, jest ten, kto w czasie popeł- } \\
\text { nienia czynu zabronionego miał ukończone lat 21. }\end{array}$ \\
\hline $\mathrm{S}$ & $\begin{array}{l}\text { Na podstawie treści art. 9 ust. 2 kk. można przyjąć, że odpowiedzialności karnej podlega osoba, } \\
\text { która w chwili czynu ukończyła 18 rok życia. }\end{array}$ \\
\hline $\mathrm{A}$ & $\begin{array}{l}\text { Z postanowień ustawy o wymiarze sprawiedliwości w sprawach czynów popełnionych przez } \\
\text { osoby nieletnie (JGG) wynika, że na podstawie kk. odpowiadają sprawcy, którzy popełnili czyn } \\
\text { zabroniony po ukończeniu 14 roku życia, jednak analiza § 36 austriackiego kodeksu karnego } \\
\text { prowadzi do wniosku, że sprawcą, wobec którego można orzec katalog kar bez żadnych ogra- } \\
\text { niczeń, jest ten, kto w chwili czynu ukończył lat 21. }\end{array}$ \\
\hline
\end{tabular}

Przypatrując się analizowanym rozwiązaniom w wybranych państwach, nie sposób pominąć standardów międzynarodowych. Należałoby zatem zwrócić uwagę przede wszystkim na postanowienia Konwencji Organizacji Narodów Zjednoczonych o Prawach Dziecka z $1989 \mathrm{r}^{48} \mathrm{~W}$ rozumieniu art. 1 Konwencji każda istota

48 Konwencja ta, będąca przejawem wyspecjalizowanego systemu ochrony i promocji praw człowieka, została ratyfikowana przez prawie 200 państw, a jej sygnatariuszem jest m.in. Polska, która podpisała Konwencję w dniu 26.01.1990 r., a następnie ratyfikowała ten dokument w dniu 7.06.1991 r. Stronami Konwencji są także opisywane w niniejszej publikacji państwa. Republika Federalna Niemiec podpisała Konwencję w dniu 26.01.1990 r., a ratyfikowała ją w dniu 6.03.1992 r., Konfederacja Szwajcarska podpisała Konwencję w dniu 1.05.1991 r., ratyfikując ją dopiero w dniu 24.02.1997 r., natomiast Austria podpisała Konwencję w dniu 26.08.1990 r. i ratyfikowała Konwencję w dniu 6.08.1992 r. Dane dotyczące terminów podpisania i ratyfikacji pochodzą z informacji zawartych na oficjalnych stronach internetowych ONZ pod adresem: http://www.un.org. 
ludzka w wieku poniżej osiemnastu lat uważana jest za „dziecko”, chyba że zgodnie z prawem odnoszącym się do dziecka uzyska ono wcześniej pełnoletność. W tym kontekście należy zauważyć, że wszystkie trzy państwa poddane analizie kształtują wiek odpowiedzialności prawnokarnej stosownie do postanowień Konwencji.

W odniesieniu do sprawców nieletnich wypada wskazać, że Niemcy, Szwajcaria i Austria nie definiują nieletniego w swoich kodyfikacjach karnych, regulując te kwestie w specjalnych pozakodeksowych ustawach dotyczących postępowania $\mathrm{z}$ tą kategorią sprawców.

Dolna granica odpowiedzialności nieletnich została ustalona najniżej w ustawie Konfederacji Szwajcarskiej, bowiem jest to lat 10. Oznacza to, że środki przewidziane w ustawie można stosować względem sprawców czynów zabronionych, którzy w chwili ich popełnienia mieli ukończone 10 lat. Ustawa niemiecka i austriacka przewidują, iż odpowiedzialności na podstawie ustawy podlegają sprawcy, którzy w chwili popełnienia czynu zabronionego mieli ukończone lat 14.

Górna granica wieku nieletniego sprawcy czynu karalnego w oparciu o przepisy ustaw dotyczących postępowania z nieletnimi wynosi w Niemczech i Szwajcarii lat 18, natomiast Austria zdecydowała się na przyjęcie modelu, w którym sprawcą nieletnim można być do ukończenia 19 roku życia. Kwestie te obrazuje zamieszczona poniżej tabela 3 .

Tabela 3. Sprawca nieletni

\begin{tabular}{|c|l|}
\hline \hline Kraj & \multicolumn{1}{|c|}{ Wiek } \\
\hline $\mathrm{N}$ & $\begin{array}{l}\text { Osoba, która w czasie popełnienia czynu zabronionego miała ukończone lat 14, ale nie ukoń- } \\
\text { czyła lat 18 (§ 1 ust. 2 ustawy o sądach dla nieletnich JGG) }\end{array}$ \\
\hline $\mathrm{S}$ & $\begin{array}{l}\text { Osoba, która popełniła czyn karalny po ukończeniu 10 roku życia, a przed ukończeniem 18 lat } \\
\text { (art. 1 ust. 1 oraz art. 3 ust. 1 ustawy karnej dla nieletnich (JStG)) }\end{array}$ \\
\hline $\mathrm{A}$ & $\begin{array}{l}\text { Osoba, które ukończyła 14 rok życia, a nie ukończyła 19 lat (§ 1 ust. 2 ustawy o wymiarze spra- } \\
\text { wiedliwości w sprawach czynów popełnionych przez osoby nieletnie (JGG)). }\end{array}$ \\
\hline
\end{tabular}

Jak już wskazano wyżej w odniesieniu do sprawców młodocianych, taka kategorią pojęciową operuje jedynie ustawodawca niemiecki, czyniąc to w ustawie o sądach dla nieletnich, co pokazuje tabela 4 . 
Czas popelnienia przestępstwa i wiek odpowiedzialności prawnokarnej w kodeksach karnych...

Tabela 4. Sprawca młodociany

\begin{tabular}{|c|l|}
\hline Kraj & \multicolumn{1}{|c|}{ Wiek } \\
\hline $\mathrm{N}$ & $\begin{array}{l}\text { Brak ustawowej definicji w kk. Zgodnie z § 1 ust. 2 ustawy o sądach dla nieletnich (JGG) } \\
\text { sprawcą młodocianym jest osoba, która w czasie popełnienia czynu zabronionego miała } \\
\text { ukończone lat 18, ale nie ukończyła lat 21 }\end{array}$ \\
\hline $\mathrm{S}$ & $\begin{array}{l}\text { Brak ustawowej definicji w kk., a także brak kategorii sprawcy młodocianego w ustawie kar- } \\
\text { nej dla nieletnich (JStG). }\end{array}$ \\
\hline $\mathrm{A}$ & $\begin{array}{l}\text { Brak ustawowej definicji w kk., a także brak kategorii sprawcy młodocianego w usta- } \\
\text { wie o wymiarze sprawiedliwości w sprawach czynów popełnionych przez osoby nieletnie } \\
\text { (JGG). }\end{array}$ \\
\hline
\end{tabular}




\title{
THE TIME OF THE OFFENSE AND THE AGE OF CRIMINAL RESPONSIBILITY IN THE PENAL CODES OF THE FEDERAL REPUBLIC OF GERMANY, THE SWISS CONFEDERATION AND AUSTRIA
}

\author{
SUMMARY
}

This paper is entitled: „The Time of the Offense and the Age of Criminal Responsibility in the Penal Codes of the Federal Republic of Germany, the Swiss Confederation and Austria." It consists of three parts containing, respectively: an introduction, analysis of legal approaches in selected countries and a summary.

The main part of the paper analyzes the German, Swiss and Austrian penal code with respect to issues related to the time of the offense and the age of criminal responsibility in these codes and laws for dealing with juvenile delinquents.

In order to facilitate comparison of regulation in selected countries in the summary also contains four tables on the time of committing the offense, and the age of criminal responsibility of juvenile offenders and adolescent. 